\title{
Determining inorganic and organic nitrogen
}

\section{Koistinen, Jaana}

Humana press

2020

Koistinen , J , Sjöblom , M \& Spilling , K 2020 , Determining inorganic and organic nitrogen . in K Spilling (ed.) , Biofuels from Algae : Methods and Protocols . vol. 1980 , Methods in Molecular Biology , Humana press, New York, pp. 71-80. https://doi.org/10.1007/7651_2018_128,https://doi.org/10.1007/7651_2019_252

http://hdl.handle.net/10138/317339

https://doi.org/10.1007/7651_2018_128

cc_by

acceptedVersion

Downloaded from Helda, University of Helsinki institutional repository.

This is an electronic reprint of the original article.

This reprint may differ from the original in pagination and typographic detail.

Please cite the original version. 
Methods in Molecular biology (2020) 1980: 71-80

DOI 10.1007/7651_2018_128

\section{Determining inorganic and organic nitrogen}

Jaana Koistinen $^{1}$, Mervi Sjöblom ${ }^{1}$, Kristian Spilling ${ }^{2}$

${ }^{1}$ Tvärminne Zoological Station, University of Helsinki, JA Palménin tie 260, 10900 Hanko, Finland

${ }^{2}$ Finnish Environment Institute, PO Box 140, 00251 Helsinki, Finland

Corresponding author:

Jaana Koistinen

Email: jaana.koistinen@helsinki.fi 


\begin{abstract}
Nitrogen $(\mathrm{N})$ is one of the key nutrients for algal growth and is an integral part of many cellular components, for example in proteins. Being able to determine the inorganic and organic pools of $\mathrm{N}$ is consequently critical for algal cultivation. In this chapter we present the methods we use for determining dissolved inorganic nitrogen (DIN), dissolved organic nitrogen (DON) and particulate organic nitrogen (PON). The methods presented here for DIN rely on colorimetric methods and those of DON and PON on filtration and high temperature catalytic oxidation.
\end{abstract}

Key words: ammonium, dissolved organic nitrogen, nitrate, nutrient uptake, particulate organic nitrogen

Running title: Determining inorganic and organic nitrogen 


\section{Introduction}

Nitrogen $(\mathrm{N})$ is one of the key nutrients for algal growth and is an integral part of many cellular components, for example in proteins. There is plenty of nitrogen around but most of it is in the form of nitrogen gas $-\mathrm{N}_{2}(\sim 78 \%$ of the atmosphere is nitrogen gas). This is not biologically available with the exception of a few nitrogen fixers that can use $\mathrm{N}_{2}$ gas, for example some cyanobacteria. The basic inorganic form of nitrogen that is used for algal growth is nitrate $\left(\mathrm{NO}_{3}^{-}\right)$, nitrite $\left(\mathrm{NO}_{2}^{-}\right)$and ammonium $\left(\mathrm{NH}_{4}{ }^{+}\right)$. In addition, some organic forms of nitrogen can be used by some algae, but large pools of dissolved organic nitrogen can yield high biomass of bacteria.

When cultivating algae it is therefore important to have some idea of the availability of inorganic nitrogen as this is a prerequisite for growth. Inorganic nitrogen is taken up and forms organic forms (e.g., protein), and being able to determine organic forms (particulate and dissolved forms) might be important for any downstream processing of the biomass and cultivation water after biomass removal.

In this chapter we present the methods we use for determining dissolved inorganic, dissolved organic, and particulate organic forms of N. The dissolved inorganic nitrogen (DIN; nitrite, nitrate and ammonium) methods are based on colorimetric principles, measuring the absorption of specific wavelengths after addition of chemicals reacting with the $\mathrm{N}$ containing molecule [1]. In $\left(\mathrm{NO}_{3}{ }^{-}+\mathrm{NO}_{2}{ }^{-}\right)$analysis, nitrate is reduced to nitrite and all nitrite in the sample is reacted with an aromatic amine, which is then coupled with another aromatic amine to form an azo dye. The reduction of nitrate to nitrite here is performed with an acidic vanadium chloride reagent [2]. Ammonium analysis is based on the formation of indophenol by phenol and hypochlorite in the presence of sodium nitroprusside. The method records also unionized 
ammonia $\left(\mathrm{NH}_{3}\right)$. Dissolved organic nitrogen (DON) can be derived from high temperature $\left(>700{ }^{\circ} \mathrm{C}\right)$ catalytic oxidation of a filtered and acidified sample [1]. The sample is sparged with synthetic air and non-purgeable dissolved nitrogen compounds are then combusted and converted to nitrogen monoxide (NO), which is cooled and detected by gas phase chemiluminescence [3] resulting total dissolved nitrogen (TDN). DON is calculated as a difference between TDN and DIN, where DIN is the sum of all dissolved inorganic nitrogen species. TDN can be determined together with total dissolved carbon (DOC), which is presented in a separate chapter. The particulate organic nitrogen $(\mathrm{PON})$ is measured simultaneously with particulate organic carbon (POC) after combustion. In this technique, the sample placed on a filter is combusted at very high temperature $\left(\sim 1000^{\circ} \mathrm{C}\right)$ in a combustion tube filled with an oxidation catalyst and oxides of $\mathrm{N}$ are reduced to $\mathrm{N}_{2}$ in reduction tube and determined by $\mathrm{CN}$ analyzer or a mass spectrometer [1].

\section{Materials}

Use only analytical grade reagents.

\subsection{Dissolved inorganic nitrogen}

1. Ammonium chloride $\left(\mathrm{NH}_{4} \mathrm{Cl}\right)$.

2. Concentrated hydrochloric acid $(37 \% \mathrm{HCl})$.

3. Disodium nitroprusside dihydrate $\left(\mathrm{Na}_{2} \mathrm{Fe}(\mathrm{CN})_{5} \mathrm{NO} \cdot 2 \mathrm{H}_{2} \mathrm{O}\right)$.

4. N-(1-naphtyl)-ethylenediamine dihydrochloride $\left(\mathrm{C}_{10} \mathrm{H}_{7} \mathrm{NHCH}_{2} \cdot \mathrm{CH}_{2} \cdot \mathrm{NH}_{2} \cdot 2 \mathrm{HCl}\right)$.

5. Phenol $\left(\mathrm{C}_{6} \mathrm{H}_{5} \mathrm{OH}\right)$.

6. Potassium nitrate $\left(\mathrm{KNO}_{3}\right)$.

7. Sodium hydroxide $(\mathrm{NaOH})$. 
8. Sulfanilamide $\left(\mathrm{NH}_{2} \cdot \mathrm{C}_{6} \mathrm{H}_{6} \cdot \mathrm{SO}_{2} \cdot \mathrm{NH}_{2}\right)$.

9. Dichloroisocyanuric acid (Trione).

10. Tri-sodium citrate dihydrate $\left(\mathrm{C}_{6} \mathrm{H}_{5} \mathrm{Na}_{3} \mathrm{O}_{7} \cdot 2 \mathrm{H}_{2} \mathrm{O}\right)$.

11. Vanadium chloride $\left(\mathrm{VCl}_{3}\right)$.

12. Ultrapure water (e.g., Milli-Q).

13. $50 \mathrm{ml}$ reaction flasks (for manual ammonium analysis).

14. $25 \mathrm{ml}$ reaction flasks with screw caps (e.g., Pyrex containers for manual nitrate analysis).

15. $50 \mathrm{ml}$ graduated cylinders.

16. $100-1000 \mathrm{ml}$ volumetric flasks.

17. $100-1000 \mathrm{ml}$ storage bottles.

18. Spatulas.

19. Adjustable pipettes and pipette tips.

20. Analytical balance.

21. Oven capable of being maintained at $45^{\circ} \mathrm{C}$.

22. Refrigerator.

$23.1 \mathrm{~cm}$ quartz glass cuvette or flow through cuvette (for manual nitrate analysis).

24. $5 \mathrm{~cm}$ quartz glass cuvette (for manual ammonium analysis).

25. Spectrophotometer or automatic analyzer.

\subsection{Dissolved organic nitrogen (total dissolved nitrogen)}

1. $24 \mathrm{ml}$ glass autosampler vials with screw caps.

2. Oven $\left(450^{\circ} \mathrm{C}\right)$.

3. Concentrated hydrochloric acid $(37 \% \mathrm{HCl})$.

4. Ultrapure water (e.g., Milli-Q). 
5. $0.7 \mu \mathrm{m}$ glass fiber filters $(25 \mathrm{~mm} \varnothing)$ and Swinnex filter holders.

6. Disposable $20 \mathrm{ml}$ sterile syringes.

7. Ammonium sulfate $\left(\mathrm{NH}_{4} \mathrm{SO}_{4}\right)$.

8. Spatulas.

9. Analytical balance.

10. 100-1000 ml volumetric flasks.

11. Adjustable pipettes, pipette tips.

12. Ultrasonicator bath.

13. Plastic film (e.g., Parafilm).

14. Refrigerator and freezer.

15. CN analyzer with autosampler and instrument specific carrier gas and oxidizing agents.

\subsection{Particulate organic nitrogen}

1. $0.7 \mu \mathrm{m}$ glass fiber filters $(25 \mathrm{~mm} \varnothing)$.

2. Concentrated hydrochloric acid $(37 \% \mathrm{HCl})$.

3. Forceps.

4. Ultrapure water (e.g., Milli-Q).

5. Oven $\left(450{ }^{\circ} \mathrm{C}\right)$.

6. Vacuum filtration device with a vacuum pump.

7. Small (30 $\mathrm{mm} \varnothing)$ disposable petri dishes.

8. Aluminum foil circles $(30 \mathrm{~mm})$.

9. Handheld plier suitable for making small balls of the aluminum foil with filter.

10. 96-well plate.

11. Bunsen burner. 
12. Ethanol (96\%).

13. Glycine $\left(\mathrm{C}_{2} \mathrm{H}_{5} \mathrm{NO}_{2}\right)$.

14. Spatulas.

15. Analytical balance.

16. $100 \mathrm{ml}$ volumetric flask.

17. Adjustable pipette, pipette tips.

18. Refrigerator.

19. CN elemental analyzer with autosampler and instrument specific carrier gas and oxidizing agents.

\section{Methods}

Use acid-washed glassware (soaked for $4 \mathrm{~h}$ in $6 \% \mathrm{HCl}$ and rinsed with deionized water).

\subsection{Nitrate and nitrite}

This method will provide the combined nitrate plus nitrite concentration. The procedure follows that of Koroleff in the first edition of [1] and [4].

1. Prepare sulfanilamide solution by dissolving $1.0 \mathrm{~g}$ sulfanilamide in a mixture of $85 \mathrm{ml}$ ultrapure water and $14.5 \mathrm{ml}$ concentrated $\mathrm{HCl}$. Store in a glass bottle at room temperature.

2. Prepare N-(1-naphtyl)-ethylenediamine dihydrochloride (NED) solution by dissolving $0.07 \mathrm{~g}$ NED in $100 \mathrm{ml}$ ultrapure water. Store in a brown glass bottle in a refrigerator (renew if the color is brown; stable about 1 month).

3. Prepare vanadium chloride solution by dissolving $0.8 \mathrm{~g}$ vanadium chloride in a mixture of $85 \mathrm{ml}$ ultrapure water and $8.4 \mathrm{ml}$ concentrated $\mathrm{HCl}$; then add ultrapure 
water to a final total volume of $100 \mathrm{ml}$. Store in glass bottle in a refrigerator (stable about 1 month).

4. Prepare $\mathrm{NO}_{3}$ mix-reagent by mixing $100 \mathrm{ml}$ vanadium chloride solution with $20 \mathrm{ml}$ sulfanilamide solution and $20 \mathrm{ml}$ amine solution. Store in a refrigerator or freeze (prolongs stability).

5. Prepare nitrate standard $140 \mu \mathrm{g} / \mathrm{ml} \mathrm{N}(10 \mu \mathrm{mol} / \mathrm{ml} \mathrm{N})$ by dissolving $0.1011 \mathrm{~g}$ potassium nitrate (pre-dried for $2 \mathrm{~h}$ at $110{ }^{\circ} \mathrm{C}$ ) in ultrapure water; then add ultrapure water to a final total volume of $100 \mathrm{ml}$. Store in a glass bottle in a refrigerator (stable about 1 month).

6. On the day of analyses, prepare working solutions of nitrate $(0-100 \mu \mathrm{g} / \mathrm{l})$ for calibration by diluting the standard stock solution (see Step 5) with ultrapure water (e.g. $1 \mathrm{ml}$ to $100 \mathrm{ml}$ for $1400 \mu \mathrm{g} / \mathrm{l}$ solution and then, e.g., $7.143 \mathrm{ml}$ of this dilution to $100 \mathrm{ml}$ ultrapure water for $100 \mu \mathrm{g} / \mathrm{l}$ solution).

7. Prepare analyzer for analyses according to the operation manual (see Note 1).

8. Place standards in the autosampler of an analyzer or measure the standards manually by a spectrophotometer for a calibration curve and linearity test (see Note 2).

9. For manual analyses, pipette three, e.g., $2 \mathrm{ml}$ portions of each working standard and three $2 \mathrm{ml}$ aliquots of ultrapure water as blanks to reaction flasks and add $2 \mathrm{ml}$ mix reagent to standards and blanks. Close the flasks, mix well by swirling and incubate for $1 \mathrm{~h}$ at $45^{\circ} \mathrm{C}$. Measure the absorbance of blanks and standards with a spectrophotometer in a $1 \mathrm{~cm}$ cuvette at $540 \mathrm{~nm}$ (see Note 2).

10. Collect the samples in glass bottles or polyethylene bottles and analyze the samples immediately after collection (within 1 hour). The sample can be stored in a glass bottle in a refrigerator for about $5 \mathrm{~h}$. 
11. Place samples in the autosampler of an analyzer or perform manual analyses with a spectrophotometer. Verify proper operation of the instrument with certified reference material and include ultrapure water blanks in the run (see Note 3).

12. For manual analyses, pipette $2 \mathrm{ml}$ aliquot of each sample with a pipette to a reaction flask, add $2 \mathrm{ml}$ mix reagent to the flask, close, mix well by swirling and incubate $1 \mathrm{~h}$ at $45^{\circ} \mathrm{C}$. Measure the absorbance of the sample in a $1 \mathrm{~cm}$ cuvette at $540 \mathrm{~nm}$ and calculate the nitrate concentration by the calibration curve (see Notes 4 and 5).

\subsection{Ammonium}

Perform analyses in a well ventilated room where no ammoniacal solutions are stored. The procedure follows that of Koroleff in the first edition of [1] and [4].

1. Prepare $0.5 \mathrm{~mol} / \mathrm{l}$ sodium hydroxide solution by dissolving $20 \mathrm{~g}$ sodium hydroxide in ultrapure water, and then add ultrapure water to a final total volume of $1000 \mathrm{ml}$. Store in a polyethylene bottle.

2. Prepare reagent II (Phenol solution) by dissolving $38 \mathrm{~g}$ phenol and $400 \mathrm{mg}$ disodium nitroprusside dihydrate in ultrapure water (protect from light by wrapping the bottle in aluminum foil) and add ultrapure water to a final volume of $1000 \mathrm{ml}$. Store in a brown glass bottle in a refrigerator (stable for months).

3. Prepare reagent I (Tri-sodium citrate solution) by dissolving $240 \mathrm{~g}$ tri-sodium citrate dihydrate in about $500 \mathrm{ml}$ ultrapure water. Add $20 \mathrm{ml} 0.5 \mathrm{~mol} / \mathrm{l}$ sodium hydroxide solution and anti-bumping granules and boil the solution until the volume is below $500 \mathrm{ml}$ to remove ammonia. Cool and add ultrapure water to a final volume of 500 $\mathrm{ml}$. Store in a brown glass bottle. 
4. Prepare reagent III (Trione solution) by dissolving $0.25 \mathrm{~g}$ Trione in $100 \mathrm{ml} 0.5 \mathrm{~mol} / \mathrm{l}$ $\mathrm{NaOH}$. Store in a brown glass bottle in a refrigerator (stable for approximately 3 days).

5. Prepare ammonium standard $140 \mu \mathrm{g} / \mathrm{ml} \mathrm{N}(10 \mu \mathrm{mol} / \mathrm{ml})$ by dissolving $0.1338 \mathrm{~g}$ ammonium chloride (predried at $100^{\circ} \mathrm{C}$ for $1 \mathrm{~h}$ ) in ultrapure water and then add ultrapure water to a final volume of $250 \mathrm{ml}$. Add a drop of chloroform for preservation. Store in a glass bottle in a refrigerator (stable for approximately 1 month).

6. On the day of analyses, prepare suitable working solutions of ammonium (0-100 $\mu \mathrm{g}$ N/l) for calibration by diluting the standard stock solution (see Step 5) with ultrapure water.

7. Measure the standards manually by a spectrophotometer for a calibration curve and linearity test (see Note 2).

8. Measure $35 \mathrm{ml}$ of working standards and $35 \mathrm{ml}$ ultrapure water for blanks with graduated cylinder and pour into reaction flasks.

9. Add $1 \mathrm{ml}$ citrate solution, $1 \mathrm{ml}$ phenol solution, and $1 \mathrm{ml}$ trione solution to standards and blanks. Swirl between additions to mix and close the flasks. Let stand overnight in dark at room temperature.

10. Measure the absorbance of blanks and standards in a $5 \mathrm{~cm}$ cuvette at $630 \mathrm{~nm}$ for the calibration curve (see Note 2).

11. Collect the samples in glass bottles or polyethylene bottles and analyze the samples immediately after collection. The sample can be stored in a glass bottle in a refrigerator for about $3 \mathrm{~h}$. 
12. Perform manual analyses with a spectrophotometer. Verify proper operation of the instrument with certified reference material and include ultrapure water blanks in the run (see Note 3).

13. Measure two $35 \mathrm{ml}$ aliquots of each sample with a graduated cylinder to reaction flasks (sample and reference; see Note 5).

14. Add $1 \mathrm{ml}$ citrate reagent, $1 \mathrm{ml}$ phenol solution and $1 \mathrm{ml}$ trione solution to the sample flask. Add $1 \mathrm{ml}$ citrate solution and $2 \mathrm{ml}$ ultrapure water to reference sample for turbidity. Swirl between additions to mix and close the flask. Let stand overnight at dark at room temperature.

15. Measure the absorbance of samples in a $5 \mathrm{~cm}$ cuvette at $630 \mathrm{~nm}$ and calculate the ammonium concentration by the calibration curve (see Note 4).

\subsection{Dissolved organic nitrogen (total dissolved nitrogen, TDN)}

1. Combust the vials for $4 \mathrm{~h}$ at $450{ }^{\circ} \mathrm{C}$, and cool them to room temperature before use.

2. Prepare $2 \mathrm{~mol} / \mathrm{l} \mathrm{HCl}$ by dissolving $33.2 \mathrm{ml}$ concentrated hydrochloric acid in ultrapure water and fill up to a volume of $200 \mathrm{ml}$. Store in a glass bottle.

3. Filter the sample with the syringe and syringe filter. Rinse the syringe with the sample before filtering. Discard first $5 \mathrm{ml}$ of the filtrate and collect $20 \mathrm{ml}$ into the glass vial. Prepare filter blank by filtering ultrapure water.

4. Add $80 \mu 12 \mathrm{~mol} / \mathrm{l} \mathrm{HCl}$ to the vial.

5. Put on the lid and place the vial in the refrigerator or freezer until it can be run in the nitrogen analyzer (see Note 6).

6. Prepare a stock standard solution containing $1000 \mathrm{mg} \mathrm{N} / 1$ by dissolving $4.716 \mathrm{~g}$ ammonium sulphate (pre-dried at $105^{\circ} \mathrm{C}$ for $1 \mathrm{~h}$ ) in ultrapure water and fill up to a 
volume of 11 . Store the stock solution in a glass flask in the refrigerator (stable for 1 month).

7. At the time of measurement, prepare suitable working standards (e.g., $0-1 \mathrm{mg} / \mathrm{l})$ for the calibration of the analyzer (see Note 7). Prepare an intermediate standard solution $100 \mathrm{mg} / \mathrm{l}$ from the stock solution and pipette appropriate amounts of this solution and $2 \mathrm{~mol} / \mathrm{l} \mathrm{HCl}(200 \mu \mathrm{l} / 100 \mathrm{ml})$ for working standards into volumetric flasks., and fill with ultrapure water (for blanks only ultrapure water and $\mathrm{HCl}$ ). Calibration standards should be made weekly.

8. Fill each calibration vial about $1 / 2$ to $2 / 3$ full, put on a plastic film (see Note 8 ), and make holes on the film with a clean syringe needle.

9. Prepare the TDN analyzer for analyses according to the operation manual (see Note $1)$.

10. Place standards in the autosampler of an analyzer and run the standards for TDN calibration curve and linearity test (see Note 2).

11. On the day of analyses, take samples out of refrigerator/freezer and let them get room temperature before further processing.

12. Place the samples in an ultrasonication bath for 10 minutes.

13. Remove the lids, put on a plastic film (see Note 8), and make holes on the film with a clean syringe needle.

14. Run samples with the analyzer (see Note 9). Verify proper operation of the instrument with reference material (Consensus Reference Water or equivalent) and include ultrapure water blanks in the run (see Note 3 ).

15. Calculate DON by subtracting DIN from TDN. 


\subsection{Particulate organic nitrogen}

1. Prepare glass fiber filters by placing them in an acid bath $(6 \% \mathrm{HCl})$ for $4 \mathrm{~h}$ and rinse then thoroughly with plenty of ultrapure water (see Note 10).

2. Combust the filters and aluminum circles for $4 \mathrm{~h}$ at $450{ }^{\circ} \mathrm{C}$ and cool to room temperature.

3. Place a filter in the filtration device and apply suction with the vacuum pump.

4. Pipette a known volume of culture through the filter (see Note 11).

5. Remove the filter with forceps while the suction is on (see Note 12).

6. Place the filter in the Petri dish, and dry it (see Note 13). For blanks, place pure glass fiber filters in the Petri dishes.

7. Prepare a standard solution by dissolving $1.340 \mathrm{~g}$ glycine in ultrapure water and fill up to a volume of $100 \mathrm{ml}$. Store the stock solution in a glass flask in the refrigerator (stable for 1 month).

8. Prepare standards for calibration of the analyzer by adding a known volume (e.g., 40 $\mu 1)$ glycine stock solution onto pure glass fiber filters and dry the filters (see Note 13).

9. Place filters on the aluminum circles, one filter per circle.

10. Fold with two clean forceps (cleaned with ethanol and quickly put into the flame of the Bunsen burner).

11. Make into a small ball with the handheld plier.

12. Put the small balls into a 96-well plate (see Note 14).

13. At the time of the measurement, prepare the $\mathrm{CN}$ analyzer for analyses according to the operation manual (see Note 1).

14. Place the aluminum balls in the autosampler of the $\mathrm{CN}$ analyzer (see Note 15). Verify proper operation of the instrument with certified reference material and include blanks in the run (see Note 3). 


\section{Notes}

1. It is critical to have proper training before running the analyzer. This will depend on the system that you are using and it is beyond the scope of this chapter to go into the details of the operation of the instrument. We have used Aquakem 250 analyser for nitrate/nitrite, Shimadzu TOC-V $\mathrm{VPH}_{\mathrm{CP}}$ with ASI-V auto sampler and TNM-1 Total Nitrogen detector for TDN and Europa Scientific ANCA 20-20 Stable Isotope Analyser with a Roboprep-CN Biological Sample Converter for PON.

2. Calibration curve is prepared by plotting measured absorbance or area of standards versus standard concentrations (linear regression).

3. Start each sample run with blank(s) and reference material to verify proper operation of the instrument. Analyze samples in sequences of max 20 samples followed by a blank and reference material. Insert also standards in the sequence to test accuracy and drift during the analytical runs.

4. Determine concentration in the sample by the slope of the calibration curve. Reduce the absorbance of the blank/reference from the absorbance of the sample.

5. If concentration is $>100 \mu \mathrm{g} / \mathrm{l}$, prepare diluted sample.

6. These can be stored short term (2-3 weeks) in refrigerator or alternatively in the freezer for 6 months.

7. Use ca. 5-10 different dilution steps for calibration depending on the concentration span of the samples.

8. This is to prevent contamination of other samples in case of bubbles forming during measurements.

9. In Shimadzu TOC- $\mathrm{V}_{\mathrm{CPH}}$ system, the sample is purged with $\mathrm{CO}_{2}$ free air to remove inorganic purgeable species, then an aliquot is injected onto a combustion tube filled with platinum-coated alumina beads, and combustion products are measured by the 
analyzer. Non-purgeable dissolved nitrogen compounds are converted to NO, which is mixed with ozone chemiluminescence and detected by a photomultiplier.

10. Using a large filtration device (e.g., $50 \mathrm{~mm} \varnothing$ ) you may place several filters on top of each other and suck ultrapure water through the filters.

11. There should be a clear color on the filter, but not forming a 'cake' of biomass.

12. This is to minimize the water content as much as possible.

13. Make sure to use lids not closing the Petri dish completely, or alternatively use some aluminum foil, to let the filter dry completely. The filter can be stored at room temperature in a desiccator.

14. Note, marking the sample name with well plate name makes it easy to follow the samples.

15. In our instrument the combustion tube is filled with an oxidation catalyst $\left(\mathrm{Cr}_{2} \mathrm{O}_{3}\right)$, $\mathrm{CuO}$ wire, and $\mathrm{Ag}$ wool and reduction tube with $\mathrm{Cu}$ wires. The balls are combusted at $1000{ }^{\circ} \mathrm{C}$ to oxidase hydrocarbons and combustion products $\left(\mathrm{N}_{2}, \mathrm{NOx}\right.$, etc.) are transferred through a reduction tube (reduce oxides of $\mathrm{N}$ to $\mathrm{N}_{2}$ ) for measurement in the detector of the analyzer.

\section{References}

[1] Grasshoff K, Ehrhardt M, Kremling K (1999) Methods of seawater analysis. Wiley-VCH Verlag Gmbh, Weinheim.

[2] Schnetger B, Lehners C (2014) Determination of nitrate plus nitrite in small volume marine water samples using vanadium(III)chloride as a reduction agent. Mar.Chem. 160:9198. 
[3] Hutte RS, Sievers RE, Birks JW (1986) Gas chromatography detectors based on chemiluminescence. J Chromatogr Sci 24:499-505.

[4] Koroleff F (1979) Methods for the chemical analysis for seawater. Meri 7: 1-60 (in Finnish). 